\title{
Novel flax orbitide derived from genetic deletion
}

\author{
Peta-Gaye Gillian Burnett ${ }^{1 *+}$, Lester Warren Young ${ }^{1 \dagger}$, Clara Marisa Olivia², Pramodkumar Dinkar Jadhav', \\ Denis Paskal Okinyo-Owiti ${ }^{1}$ and Martin John Tarsisius Reaney ${ }^{1,3^{*}}$
}

\begin{abstract}
Background: Flaxseed orbitides are homodetic plant cyclic peptides arising from ribosomal synthesis and posttranslation modification (N to C cyclization), and lacking cysteine double bonds (Nat Prod Rep 30:108-160, 2013). Screening for orbitide composition was conducted on the flax core collection (FCC) grown at both Saskatoon, Saskatchewan and Morden, Manitoba over three growing seasons (2009-2011). Two flax (Linum usitatissimum L.) accessions 'Hollandia' (CN 98056) and 'Z 11637' (CN 98150) produce neither [1-9-NaC]-linusorb B2 (3) nor [1-9$\mathrm{NaCl}$-linusorb B3 (1). Mass spectrometry was used to identify novel compounds and elucidate their structure. NMR spectroscopy was used to corroborate structural information.

Results: Experimental findings indicated that these accessions produce a novel orbitide, identified in three oxidation states having quasimolecular ion peaks at $\mathrm{m} / \mathrm{z} 1072.6(18), 1088.6(19)$, and $1104.6(20)[\mathrm{M}+\mathrm{H}]^{+}$ corresponding to molecular formulae $\mathrm{C}_{57} \mathrm{H}_{86} \mathrm{~N}_{9} \mathrm{O}_{9} \mathrm{~S}, \mathrm{C}_{57} \mathrm{H}_{86} \mathrm{~N}_{9} \mathrm{O}_{10} \mathrm{~S}$, and $\mathrm{C}_{57} \mathrm{H}_{86} \mathrm{~N}_{9} \mathrm{O}_{11} \mathrm{~S}$, respectively. The structure of 19 was confirmed unequivocally as [1-9-NaC]-OLIPPFFLI. PCR amplification and sequencing of the gene coding for 18, using primers developed for 3 and 1, identified the putative linear precursor protein of 18 as being comprised of the first three amino acid residues of $\mathbf{3}(\mathrm{MLI})$, four conserved amino acid residues of 3 and/or 1 (PPFF), and the last two residues of 1 (LI).

Conclusion: Comparison of gene sequencing data revealed that a 117 base pair deletion had occurred that resulted in truncation of both 3 and 1 to produce a sequence encoding for the novel orbitide precursor of 18 . This observation suggests that repeat units of flax orbitide genes are conserved and suggests a novel mechanism for evolution of orbitide gene diversity. Orbitides 19 and 20 contain $\mathrm{MetO}$ and $\mathrm{MetO}_{2}$, respectively, and are not directly encoded, but are products of post-translation modification of Met present in 18 ([1-9-NaC]-MLIPPFFLI).
\end{abstract}

Keywords: Linum usitatissimum L., Orbitides, Cyclolinopeptides, Plant genetic resources, Mass spectrometry, Sequencing

\section{Background}

Orbitides can be found in plant families and genera other than Linaceae and Linum, including Annonaceae (Panax), Caryophyllaceae (Saponaria), Euphorbiaceae (Jatropha), and Rutaceae (Citrus) [1-3]. Although their biological function is unknown, they are thought to serve an important role due to their abundance and conserved nature. Orbitides, like other macrocylic peptides, are resistant to protease digestion due to covalently

\footnotetext{
*Correspondence: pete.burnett@usask.ca; martin.reaney@usask.ca ${ }^{\dagger}$ Equal contributors

${ }^{1}$ Department of Plant Sciences, College of Agriculture and Bioresources, University of Saskatchewan, Saskatoon, SK S7N 5A8, Canada Full list of author information is available at the end of the article
}

closed ends which may be critical for biological activity [4]. Potential biological activities of flax orbitides and their analogs have been investigated over the past two decades [5-16] and the results summarized in a review [17]. To date, eleven parent flaxseed orbitides $(\mathbf{1}, \mathbf{2}, \mathbf{5}, \mathbf{7}$, 10, 14, 21, 23-25 and 27) have been discovered and the corresponding DNA sequences encoding precursor proteins have been identified [18-20] from the flax genome database [21] (Fig. 1, Additional file 1: Table S1). The remaining flax orbitides reported in the literature $(3, \mathbf{4}$, $6,8,9,11-13,15-17,22,26$ and 28) result from methionine post-translational oxidation.

All linear proteins containing orbitide domains are encoded by genes. These linear precursor proteins share 


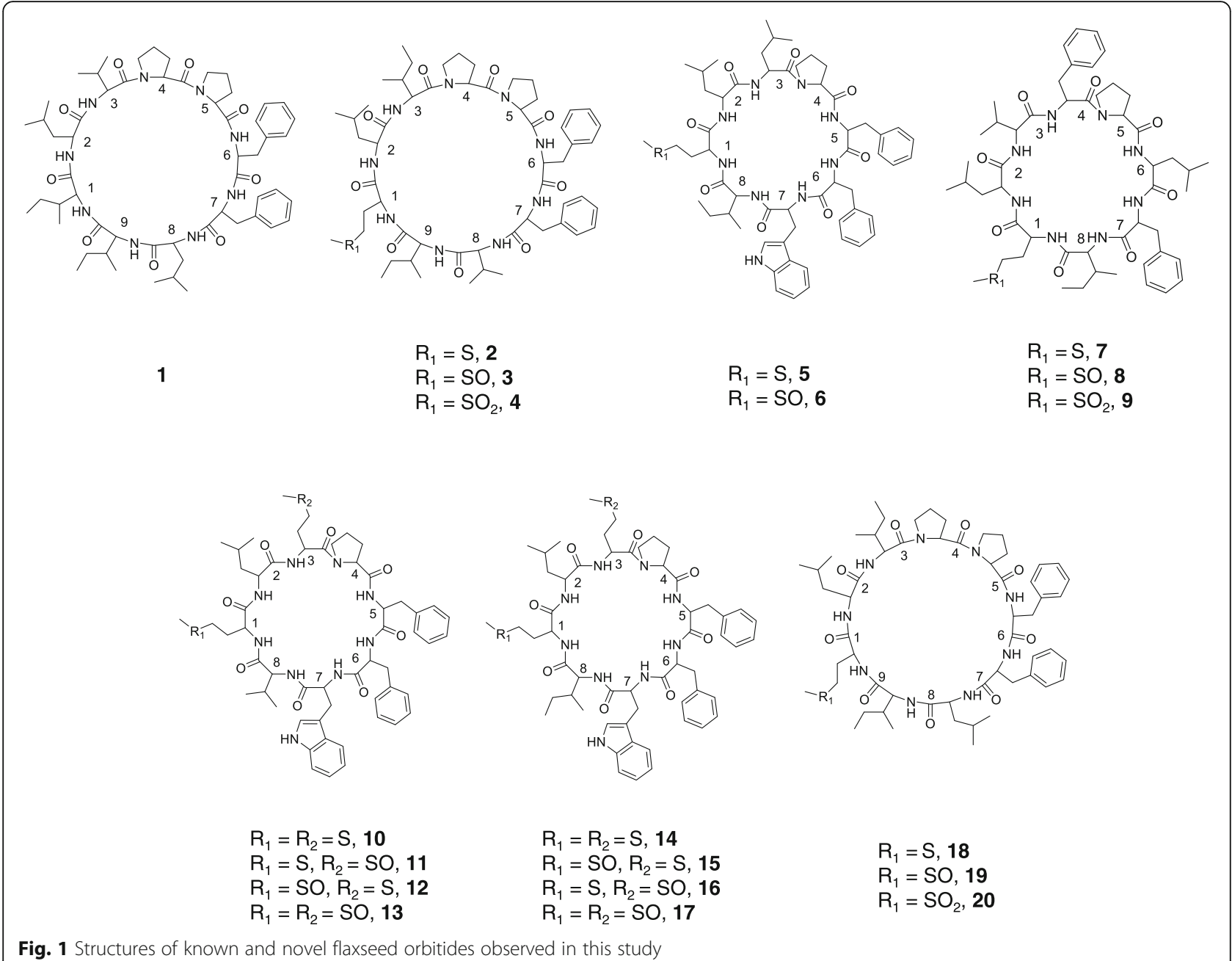

structural similarities. In L. usitatissimum, orbitide domains are flanked predominantly by "DD", "DG" or "SD" residues at the amino termini, and "FGK" or "VGK" residues at the carboxy termini. Additionally, some of these orbitide domains are present as tandem repeats in the proprotein carboxy terminal. The orbitide precursor protein of 5,10 , and 14 has been identified in L. usitatissimum chromosome Lu14 (National Center for Biotechnology Information (NCBI) GenBank ${ }^{\mathrm{ma}}$ CP027624.1 residues 17099153 to 17099545 [21]; as these orbitides are coded by the same gene it is hereafter named LINUSORB A, following our proposed systematic nomenclature [22]) for example. The function of the first exon of this gene is unknown, while the second exon encodes a linear precursor protein with five orbitide domains arranged in repeats in the order $14,14,5,14,10$. The conserved nature of sequences flanking the orbitide coding region and occurrence of repeat units has allowed the identification of several other related putative orbitides in Citrus and Saponaria [2]. Additional gene sequences that appear to code for flax orbitides have been identified based on their conserved tandem repeat structure. However, detection of the actual orbitides remains to be established. It is not known in which tissue the gene may be expressed, or if the apparent genes are expressed at all.

\section{Results}

Recently, orbitide compositions of the flax core collection (FCC) harvested in 2009 were determined using high-performance liquid chromatography with reversedphase monolithic HPLC columns and diode array detection (HPLC-DAD) [23]. The FCC is a subset of the Canadian flax world collection curated by Plant Gene Resources of Canada (PGRC) comprising 381 accessions [24]. The FCC was assembled to represent the phenotypic diversity and genetic variability of approximately 3500 flax accessions from around the world held in the Canadian collection. The FCC currently includes 407 accessions [25]. An additional ten cultivars were included in the study of orbitides in the FCC, namely 'CDC Sorrel,' 'CDC Mons', 'Lightning,' 'Prairie Blue,' 'Prairie 
Grande, 'Prairie Thunder' and 'Shape' along with the checks 'CDC Bethune, 'Hanley', and 'Macbeth'. Screening was limited to orbitides $\mathbf{1}, \mathbf{3}$, and $\mathbf{8}$ (encoded by the gene contained within L. usitatissimum chromosome Lu11; National Center for Biotechnology Information (NCBI) GenBank $^{\text {Tm }}$ Sequence ID: CP027621.1 residues 2516493 to 2517107 [21]; Hereafter, LINUSORB B following our proposed systematic nomenclature [22]) and orbitides $\mathbf{6}$, 13, and 17 (encoded by LINUSORB A). These orbitides were chosen because of their high expression and known chromatographic separation methods. 'Hollandia' (CN 98056) and ' $\mathrm{Z}$ 11637' (CN 98150), both originated from The Netherlands, and were identified as accessions expressing the lowest total orbitide content and the lowest apparent concentration ratio of orbitides $[\mathbf{1}, \mathbf{3}, \mathbf{8}]$ to $[\mathbf{6}$, 13, 17]. Closer evaluation revealed that the differences were attributed to a lack of $\mathbf{1}$ and $\mathbf{3}$, while the apparent concentration of $\mathbf{8}$ was comparable to the mean of the core collection. Expression of 6, 13 and 17 in these accessions was not significantly different from the rest of the core collection.

Orbitide compositions of oxidized extracts from accessions 'Hollandia' and 'Z 11637' were compared in detail with orbitides of 'CDC Bethune'. The HPLC-DAD chromatograms displayed elution peaks at approximately 2.5 ,
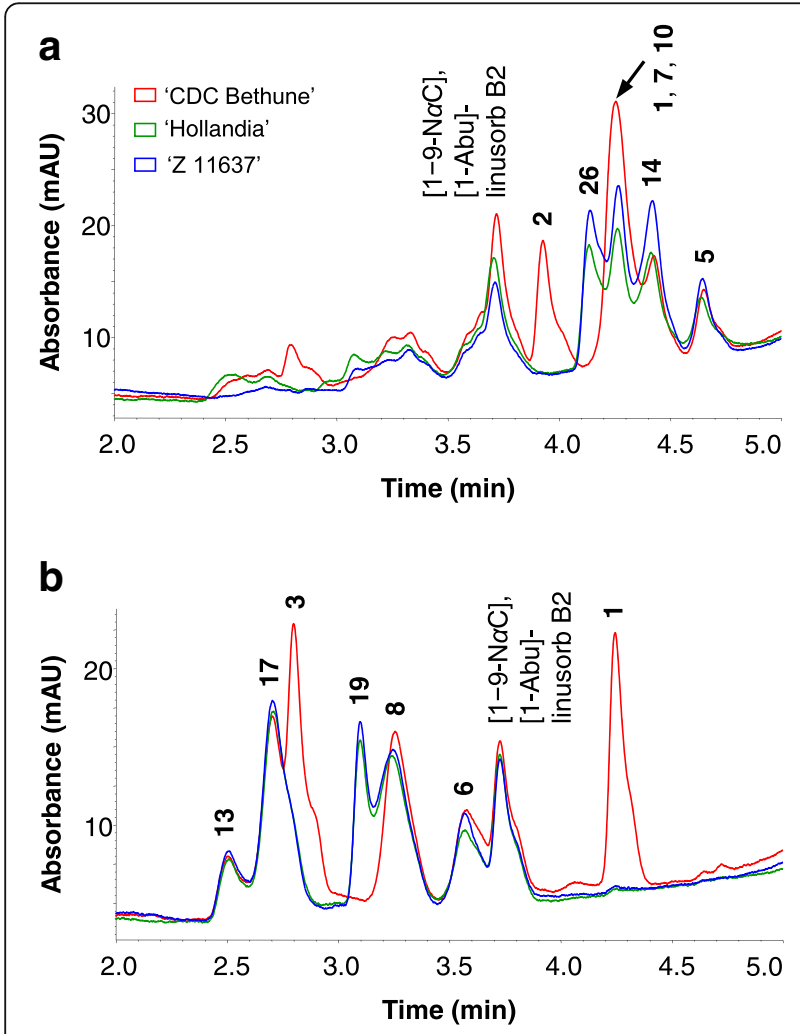

Fig. 2 HPLC-DAD chromatograms of flaxseed (L. usitatissimum) 'CDC Bethune', 'Hollandia', and 'Z 11637' orbitide extracts. a unoxidized and $\mathbf{b}$ oxidized
$2.7,2.8,3.3,3.6$, and $4.3 \mathrm{~min}$ corresponding to $\mathbf{1 3}, \mathbf{1 7}, \mathbf{3}$, $\mathbf{8 , 6}$, and $\mathbf{1}$, respectively (Fig. 2a). Orbitides $\mathbf{1}$ and $\mathbf{3}$ were either not detected or were detected at low concentrations in 'Hollandia' and ' $\mathrm{Z}$ 11637', while expression of 8 in these accessions was comparable to that of ' $\mathrm{CDC}$ Bethune'. Hence, orbitide concentrations of 1:3:8 observed in 'Hollandia' and ' $Z$ 11637' deviated from the 1:1:1 ratio expressed in 'CDC Bethune'. These findings were consistent regardless of harvest location (Saskatoon, SK or Morden, MB) and year $(2009,2010,2011)$ and corroborate observations made by Burnett et al. [23] (Table 1). Low level detection of $\mathbf{1}$ and $\mathbf{3}$ in 'Hollandia' and ' $\mathrm{Z}$ 11637 ' resulted from flaxseed samples that were contaminated with one or more other accessions within the FCC. Such contamination is not uncommon in field plot studies. In 2009, mean total orbitide contents of 'Hollandia, 'Z 11637' and 'CDC Bethune' were 139.2, 106.9 (Table 1) and 196.9 mAU [23]. Similar total orbitide concentrations in 'Hollandia' and 'Z 11637' were observed in 2010 and 2011 with mean 2010 values being lower probably due to poor seed quality from the Saskatoon plots that year. Plant maturity at harvest was atypical because of a short growing season (from delayed seeding) with excess moisture. Overall, the sum of apparent orbitide concentrations of $\mathbf{1}, \mathbf{3}$, and $\mathbf{8}$ (encoded by LINUSORB $B$ ), hereafter refered to as $[\mathbf{1}, \mathbf{3}, \mathbf{8}]$, were lower than those of $\mathbf{6}, \mathbf{1 3}$, and 17 (encoded by LINUSORB A), hereafter refered to as $[\mathbf{6}, \mathbf{1 3}, \mathbf{1 7}]$. The mean apparent concentration ratio of $[\mathbf{1 , 3 , 8}]$ to $[\mathbf{6 , 1 3}, \mathbf{1 7}]$ observed in accessions 'Hollandia' and ' $\mathrm{Z}$ 11637' over three growing seasons was $0.7 \pm 0.2$, while that observed in 'CDC Bethune' in 2009 was $1.9 \pm 0.1$ [23]. These ratios were consistent regardless of harvest location and reflected the apparent low total orbitide expression of these accessions.

An unidentified compound, at retention time $3.1 \mathrm{~min}$, (18) was detected in HPLC-DAD chromatograms of oxidized orbitide extracts from 'Hollandia' and 'Z 11637, suggesting the presence of a novel compound (Fig. 2a). Orbitide extracts from these two accessions were analyzed without addition of hydrogen peroxide to determine whether the new peak corresponded to an oxidation product or to a compound unaffected by oxidation. The HPLC-DAD analyses of unoxidized extracts of 'CDC Bethune' showed the presence of 2, 14 and $\mathbf{5}$ eluting at 3.9, 4.4 and $4.7 \mathrm{~min}$, respectively, along with the co-elution of $\mathbf{1}, 7$ and $\mathbf{1 0}$ at $4.3 \mathrm{~min}$ (confirmed by HPLC-ESI-MS and HPLC-ESI-MS/MS analyses) (Fig. 2b). Stefanowicz [26], Okinyo-Owiti et al. [20], and Burnett et al. [23] have reported similar observations for orbitide content of fresh flaxseed extracts. Unoxidized flaxseed extracts from 'Hollandia' and ' $\mathrm{Z}$ 11637' contained known orbitides $7, \mathbf{1 0}, \mathbf{1 4}$, and 15 as found in 'CDC Bethune'. However, in contrast to "CDC Bethune', 
Table 1 Average orbitide distribution in oxidized aqueous methanolic extracts of 'Hollandia' and 'Z 11637' flaxseed accessions

\begin{tabular}{|c|c|c|c|c|c|c|}
\hline \multirow[t]{2}{*}{ Orbitide (mAU) } & \multicolumn{3}{|l|}{ 'Hollandia' } & \multicolumn{3}{|l|}{ 'Z 11637' } \\
\hline & 2009 & 2010 & 2011 & & 2010 & 2011 \\
\hline 1 & $2.0 \pm 2.4$ & $7.9 \pm 9.2$ & $10.7 \pm 4.6$ & $0.0 \pm 0.0$ & $0.9 \pm 1.2$ & $2.2 \pm 2.5$ \\
\hline 3 & $1.7 \pm 1.9$ & $8.1 \pm 9.5$ & $10.1 \pm 4.8$ & $0.0 \pm 0.0$ & $1.3 \pm 1.5$ & $1.4 \pm 1.6$ \\
\hline 6 & $19.1 \pm 4.4$ & $14.1 \pm 0.6$ & $17.0 \pm 1.8$ & $15.5 \pm 3.2$ & $13.7 \pm 5.0$ & $17.7 \pm 1.9$ \\
\hline 8 & $48.2 \pm 22.2$ & $38.1 \pm 1.3$ & $39.8 \pm 2.3$ & $36.2 \pm 5.8$ & $34.3 \pm 7.2$ & $35.3 \pm 2.8$ \\
\hline 13 & $16.9 \pm 3.1$ & $13.5 \pm 1.2$ & $15.2 \pm 0.9$ & $13.5 \pm 2.2$ & $9.8 \pm 4.3$ & $13.9 \pm 1.0$ \\
\hline 17 & $51.2 \pm 10.6$ & $38.5 \pm 2.8$ & $43.8 \pm 3.2$ & $41.7 \pm 6.3$ & $31.9 \pm 13.1$ & $44.4 \pm 2.3$ \\
\hline 19 & $38.6 \pm 7.3$ & $29.8 \pm 2.5$ & $28.3 \pm 6.9$ & $35.4 \pm 5.3$ & $29.4 \pm 6.2$ & $31.9 \pm 2.7$ \\
\hline Total orbitide & $139.2 \pm 33.4$ & $121.4 \pm 21.8$ & $135.0 \pm 6.5$ & $106.9 \pm 17.4$ & $91.9 \pm 26.9$ & $114.9 \pm 5.8$ \\
\hline$[1,3,8] /[6,13,17]$ & $0.6 \pm 0.2$ & $0.8 \pm 0.3$ & $0.8 \pm 0.1$ & $0.5 \pm 0.0$ & $0.7 \pm 0.2$ & $0.5 \pm 0.0$ \\
\hline
\end{tabular}

Data are presented as mean values (peak area in $\mathrm{mAU}$ ) from replicate analyses from named flaxseed accessions grown in Saskatoon, SK and Morden, MB plots; $n=4$

(i) no peak was observed for 2; (ii) the absence of $\mathbf{1}$ was confirmed by mass spectrometry; and (iii) an additional peak at retention time $4.2 \mathrm{~min}(\mathbf{1 8})$ was observed in extracts from 'Hollandia' and 'Z 11637' (Fig. 2b). The lack of $\mathbf{1}$ and $\mathbf{3}$ in oxidized extracts was supported by the absence of $\mathbf{1}$ and $\mathbf{2}$ in unoxidized extracts as $\mathbf{1}$ is unaffected by oxidation, while $\mathbf{3}$ is derived from posttranslational oxidation of the methionine (Met) residue in 2 to methionine $S$-oxide (MetO). HPLC-DAD analyses of 'Hollandia' and 'Z 11637' grown at two locations over three years confirmed the consistent presence of the new peak at an apparent concentration of $32.1 \pm 5.0$ mAU. Signals in both oxidized and unoxidized extracts are consistent with a novel orbitide (18) and this orbitide is prone to oxidation.

Oxidized and unoxidized extracts of 'Hollandia', ' $\mathrm{Z}$ 11637 ' and 'CDC Bethune' were subjected to extensive HPLC-ESI-MS and HPLC-ESI-MS/MS analyses. The unidentified peak (18) occurring in unoxidized extracts possessed a quasimolecular ion at $\mathrm{m} / z$ 1072.6246 ([M + $\left.\mathrm{H}]^{+}, t_{\mathrm{R}}=7.4 \mathrm{~min}\right)$. Tandem mass spectrometry displayed ring opening at the amide nitrogen of proline followed by sequential loss of neutral single amino acid residues typical of $b$ fragmentation. The proposed mass fragmentation pattern of $\mathbf{1 8}$ is: Leu/Ile-Leu/Ile-Met-Leu/ Ile-Leu/Ile-Phe to $m / z \quad 342.18 \quad\left([\mathrm{M}+\mathrm{H}]^{+}\right.$which is attributed to the tripeptide fragment [Phe-Pro-Pro] (Fig. 3a). The HPLC-ESI-MS spectra of oxidized extracts from the anomalous accessions showed novel orbitide $19\left(\mathrm{~m} / z 1088.6211\left([\mathrm{M}+\mathrm{H}]^{+}, t_{\mathrm{R}}=3.7 \mathrm{~min}\right)\right.$, in addition to low apparent concentration of $20(\mathrm{~m} / z$ $1104.6150\left([\mathrm{M}+\mathrm{H}]^{+}, t_{\mathrm{R}}=5.7 \mathrm{~min}\right)$. Both 19 and 20 showed similar fragmentation patterns to that of $\mathbf{1 8}$, with the exception of the third, methionine-containing, residue (Figs. $3 \mathrm{~b}$ and $\mathrm{c}$ ). The third cleavage residue observed in these spectra corresponded to a loss of 147. $04 \mathrm{Da}$ and $163.03 \mathrm{Da}$ in 19 and 20, respectively. The difference (15.9949 Da) between 18 and 19, and between 19 and 20, suggests that 19 and 20 were derived from oxidative modification of Met present in $\mathbf{1 8}$ to $\mathrm{MetO}$ and $\mathrm{MetO}_{2}$, respectively. Oxidation of the Met residue to $\mathrm{MetO}$ and subsequently to $\mathrm{MetO}_{2}$ arose from addition of $\mathrm{H}_{2} \mathrm{O}_{2}$ to the extracts. Based on these assumptions, the molecular weights and tandem mass spectra, the proposed mass fragmentation pattern of $\mathbf{1 9}$ is Leu/Ile-Leu/Ile-MetO-Leu/Ile-Leu/Ile-Phe-[Phe-ProPro], while that of $\mathbf{2 0}$ is Leu/Ile-Leu/Ile-MetO ${ }_{2}-\mathrm{Leu} / \mathrm{Ile}-$ Leu/Ile-Phe-[Phe-Pro-Pro].

Orbitide 19 was isolated in sufficient quantities for further characterization via nuclear magnetic resonance (NMR). NMR spectra were conducted in deuterated chloroform and recorded at $308 \mathrm{~K}$ (Additional file 2: Figure S1, Additional file 3: Figure S2, Additional file 4: Figure S3, Additional file 5: Figure S4, Additional file 6: Figure S5, Additional file 7: Figure S6, Additional file 8: Figure S7 and Additional file 9: Figure S8). Sequential assignment of $\alpha, \beta, \gamma$ and $\delta$ protons were performed using ${ }^{1} \mathrm{H}-{ }^{1} \mathrm{H}$ correlation spectroscopy (COSY), total correlation spectroscopy (TOCSY) and Nuclear Overhauser effect spectroscopy (NOESY) experiments. In addition, hetero nuclear multiple quantum correlation (HMQC) was performed to assign carbon atoms attached to protons. Resonances arising from protons attached to heteroatoms were assigned using ${ }^{1} \mathrm{H}$ NMR data and their coupling to amide protons and carbonyl carbons employed NOE and heteronuclear multiple-bond correlation (HMBC) spectroscopy, all of which collectively confirmed the orbitide amino acid sequence. The NMR spectral data of 19 (Fig. 4, Table 2) showed remarkable similarities to that of $\mathbf{3}$ which is not surprising as the calculated molecular weight of $19(\mathrm{~m} / z 1088$. $6213\left([\mathrm{M}+\mathrm{H}]^{+}, \mathrm{C}_{57} \mathrm{H}_{86} \mathrm{~N}_{9} \mathrm{O}_{10} \mathrm{~S}\right)$ is $14.0157 \mathrm{Da}$ higher than that of $3\left(\mathrm{~m} / z 1074.6056\left([\mathrm{M}+\mathrm{H}]^{+}, \mathrm{C}_{56} \mathrm{H}_{84} \mathrm{~N}_{9} \mathrm{O}_{10} \mathrm{~S}\right.\right.$, [1-9$\mathrm{N} \alpha \mathrm{C}$ ]-OLIPPFFVI) (Additional file 1: Table S1), thereby suggesting the presence of an additional methylene moiety [9]. ${ }^{1} \mathrm{H}$ NMR data of 19 displayed most resonances also observed in that of 3 . However, the ${ }^{1} \mathrm{H}$ NMR spectrum of 

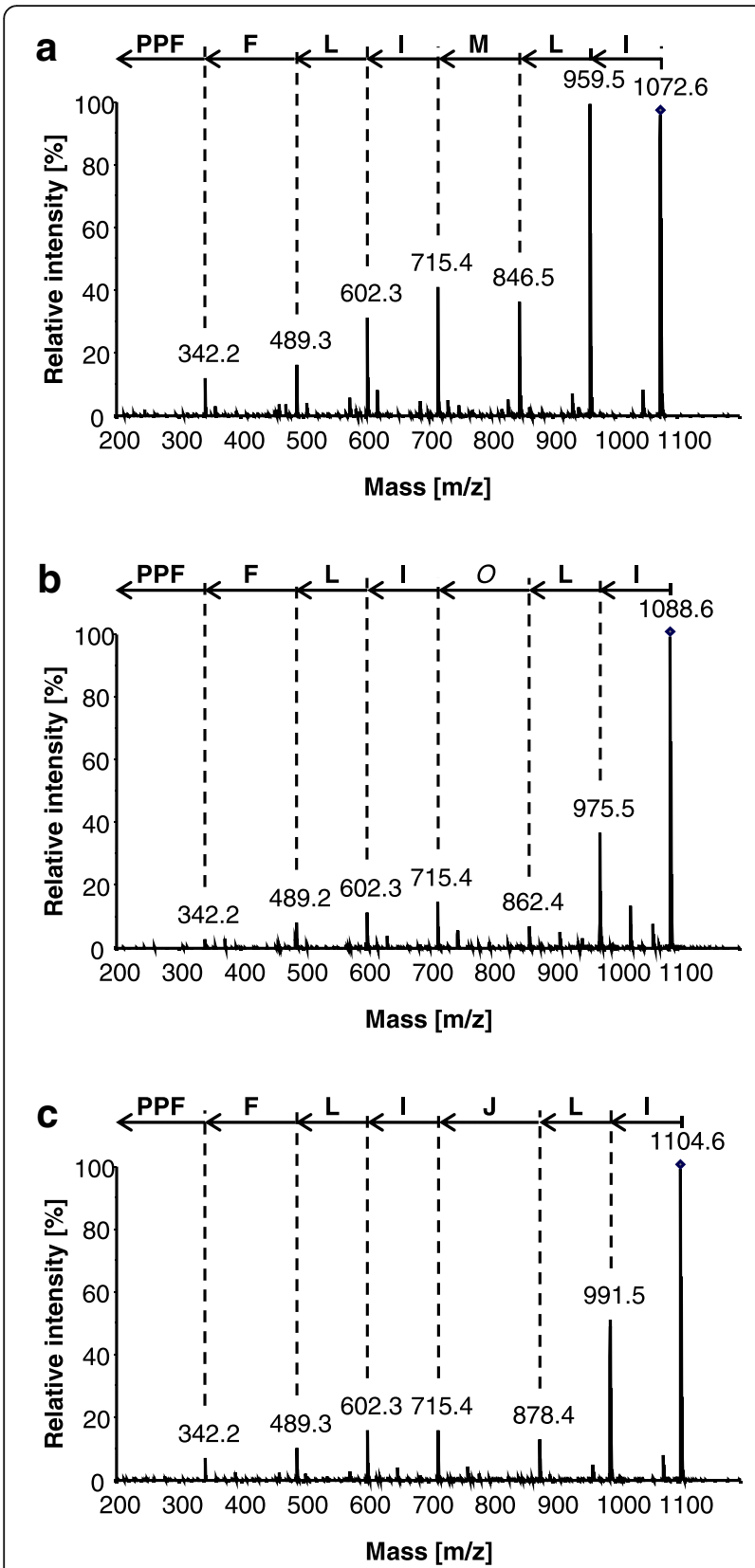

Fig. 3 Product ion spectra of ions derived from 18, 19, and 20. a [1-9-NaC]-MLIPPFFLI $\left(18, \mathrm{~m} / \mathrm{z}\right.$ 1072.6246) at $t_{R} 7.4 \mathrm{~min}, \mathbf{b}$ [1-9$\mathrm{NaC}$-OLIPPFFLI $(19, \mathrm{~m} / \mathrm{z} 1088.6211)$ at $t_{\mathrm{R}} 3.7 \mathrm{~min}$, and $\mathbf{c}$ [1-9-NaC]JLIPPFFLI $(20, \mathrm{~m} / \mathrm{z} 1104.6150)$ at $t_{\mathrm{R}} 5.7 \mathrm{~min}$

19, unlike 3, displayed two sharp singlets at $\delta 2.54$ and 2 . $56 \mathrm{ppm}$ and carbon signals at $\delta 38.17$ and $38.73 \mathrm{ppm}$ that correspond to methyl of a MetO moiety. Note that $\mathbf{3}$ in deuterated dimethyl sulfoxide exhibited only one MetO singlet at $\delta 2.45 \mathrm{ppm}$ and a carbon signal at $\delta 37.6 \mathrm{ppm}$ [9]. These observations suggest that 19 existed in two stable conformers under the NMR experimental conditions employed and that the MetO exists in $\mathrm{R}$ or $\mathrm{S}$ diastereomeric forms. The ${ }^{1} \mathrm{H}$ NMR revealed seven amide

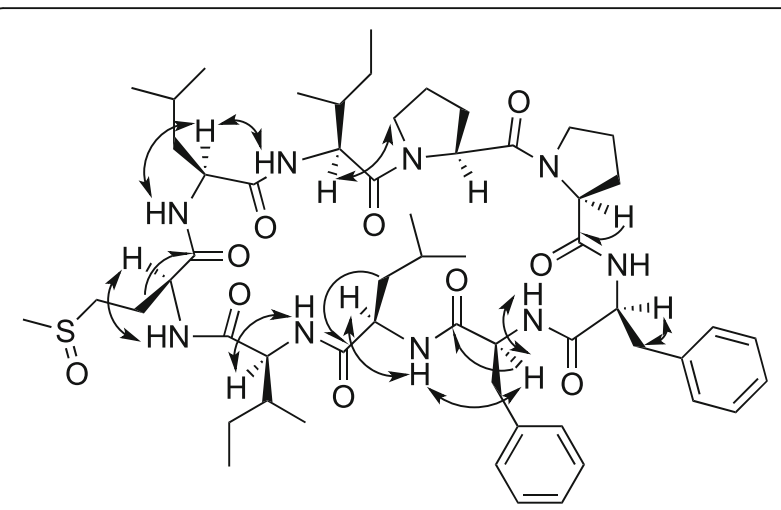

Fig. 4 Structure of 19 ([1-9-NaC]-OLIPPFFLI). Double arrows show selected NOESY correlations, while half arrows show selected $\mathrm{HMBC}$ correlations

proton signals $(\delta 6.74,6.95,7.45,7.48,7.65(2)$, and 7. $76 \mathrm{ppm}$ ) (Table 2). The ${ }^{13} \mathrm{C}$ NMR spectrum showed two sets of signals for each carbon atom corresponding to two conformers; signals from the major conformer are shown in Table 2. Nine amide carbonyl signals $(\delta 170.69,170.77$, $171.14,171.40,171.50,172.42,172.74,172.98$, and $173.36 \mathrm{ppm}$ ) were observed in ${ }^{13} \mathrm{C}$ NMR indicating that 19 is a nonapeptide. NMR analyses (Table 2) showed the presence of Leu in $\mathbf{1 9}$ instead of Val as detected in 3 [9]. The NMR spectroscopic data clearly distinguishes between Leu and Ile residues and further corroborated mass spectral analyses thus confirming the structure of 19 as: Ile-Leu-MetO-Ile-Leu-Phe-PhePro-Pro.

Orbitides, by definition, are ribosomally synthesized and post-translationally modified N-to-C linked peptides. Consequently, compounds 18, 19, and 20 cannot be unequivocally classified as orbitides until their corresponding biosynthetic precursor is identified. Based on the mass fragmentation pattern of $\mathbf{1 9}$ and its homology with 3, the proposed sequence of the mature genetically encoded 18 is [1-9-N $\alpha \mathrm{C}$ ]-MLIPPFFLI. Based on the recently proposed systematic nomenclature of flax orbitides $[17,22]$, novel orbitides 18 ([1-9-N $\alpha \mathrm{C}]$ MLIPPFFLI), 19 ([1-9-N $\alpha \mathrm{C}]$-OLIPPFFLI), and 20 ([1-9$\mathrm{N} \alpha \mathrm{C}]$-JLIPPFFLI) are designated [1-9-N $\alpha \mathrm{C}]$-linosorb $\mathrm{F} 1$, [1-9-N $\alpha \mathrm{C}]$-[1-MetO]-linosorb $\quad \mathrm{F} 1, \quad[1-9-\mathrm{N} \alpha \mathrm{C}]-[1-$ $\left.\mathrm{MetO}_{2}\right]$-linosorb F1, respectively. Although an assembly of the entire L. usitatissimum genome has been published [21], the genomic data is constructed only from the cultivar 'CDC Bethune'. Nevertheless, we conducted TBLASTN $[27,28]$ searches using default algorithm parameters with a putative precursor for 18, MLIPPFFLI, as the initial query in addition to all possible linear transcripts for 18. The searches returned no hits which is not surprising given that the observed changes in orbitide production in 'Hollandia' and 'Z 11637' indicate that 
Table $2{ }^{1} \mathrm{H}$ and ${ }^{13} \mathrm{C}$ NMR assignments for [1-9-NaC]-OLIPPFFLI (19)

\begin{tabular}{|c|c|c|c|c|c|c|c|}
\hline \multirow{2}{*}{$\frac{\text { Assignment }}{\text { MetO }^{1}}$} & & \multirow[t]{2}{*}{$\delta_{H}$} & \multirow[t]{2}{*}{$\delta_{C}$} & \multicolumn{2}{|l|}{ Assignment } & \multirow[t]{2}{*}{$\delta_{H}$} & \multirow[t]{2}{*}{$\delta_{C}$} \\
\hline & & & & $\mathrm{Phe}^{6}$ & & & \\
\hline & $a$ & $4.78(1 \mathrm{H}, \mathrm{m})$ & 52.11 & & $a$ & $4.78(1 \mathrm{H}, \mathrm{m})$ & 54.78 \\
\hline & $\beta$ & $2.25(2 \mathrm{H}, \mathrm{m})$ & 29.93 & & $\beta$ & $2.95(2 \mathrm{H}, \mathrm{m})$ & 36.01 \\
\hline & $\gamma$ & $3.02(2 \mathrm{H}, \mathrm{m})$ & 50.09 & & Y & & 136.61 \\
\hline & $\varepsilon_{\mathrm{Me}}$ & $2.54(3 \mathrm{H}, \mathrm{s})$ & 38.17 & & $\delta$ & & 129.71 \\
\hline & $\mathrm{NH}$ & $7.76(1 \mathrm{H}, \mathrm{s})$ & & & $\varepsilon$ & & 129.02 \\
\hline & $C=O$ & & 173.36 & & $\zeta$ & & 126.84 \\
\hline \multirow[t]{9}{*}{ Leu $^{2}$} & & & & & $\mathrm{NH}$ & $7.45(1 \mathrm{H}, \mathrm{m})$ & \\
\hline & $a$ & $4.51(1 \mathrm{H}, \mathrm{m})$ & 55.82 & & $\mathrm{C}=\mathrm{O}$ & & 172.74 \\
\hline & $\beta$ & $2.25(1 \mathrm{H}, \mathrm{m})$ & 40.38 & $\mathrm{Phe}^{7}$ & & & \\
\hline & & $1.97(1 \mathrm{H}, \mathrm{m})$ & & & $a$ & $4.87(1 \mathrm{H}, \mathrm{m})$ & 54.12 \\
\hline & Y & $1.62(1 \mathrm{H}, \mathrm{m})$ & 28.55 & & $\beta$ & $3.08(2 \mathrm{H}, \mathrm{m})$ & 34.59 \\
\hline & $\delta_{\mathrm{Me}}$ & $0.93(3 \mathrm{H}, \mathrm{m})$ & 23.21 & & y & & 136.95 \\
\hline & & $0.88(3 \mathrm{H}, \mathrm{m})$ & 21.56 & & $\delta$ & & 129.97 \\
\hline & $\mathrm{NH}$ & $6.95(1 \mathrm{H}, \mathrm{m})$ & & & $\varepsilon$ & & 129.05 \\
\hline & $\mathrm{C}=\mathrm{O}$ & & 170.77 & & $\zeta$ & & 127.24 \\
\hline \multirow[t]{8}{*}{$11 \mathrm{e}^{3}$} & & & & & $\mathrm{NH}$ & $7.65(1 \mathrm{H}, \mathrm{m})$ & \\
\hline & $a$ & $4.58(1 \mathrm{H}, \mathrm{m})$ & 56.15 & & $\mathrm{C}=\mathrm{O}$ & & 171.14 \\
\hline & $\beta$ & $1.94(1 \mathrm{H}, \mathrm{m})$ & 36.89 & Leu $^{8}$ & & & \\
\hline & $\gamma$ & $1.69(2 \mathrm{H}, \mathrm{m})$ & 24.34 & & $a$ & $4.08(1 \mathrm{H}, \mathrm{m})$ & 54.98 \\
\hline & $\gamma_{\mathrm{Me}}$ & $1.07(3 \mathrm{H}, \mathrm{m})$ & 15.65 & & $\beta$ & $2.15(1 \mathrm{H}, \mathrm{m})$ & 38.73 \\
\hline & $\delta_{\mathrm{Me}}$ & $0.93(3 \mathrm{H}, \mathrm{m})$ & 11.31 & & & $1.91(1 \mathrm{H}, \mathrm{m})$ & \\
\hline & $\mathrm{NH}$ & $8.06(1 \mathrm{H}, \mathrm{br} . \mathrm{s})$ & & & Y & $1.62(1 \mathrm{H}, \mathrm{m})$ & 25.03 \\
\hline & $C=O$ & & 171.40 & & $\delta_{\mathrm{Me}}$ & $0.97(3 \mathrm{H}, \mathrm{m})$ & 23.34 \\
\hline \multirow[t]{9}{*}{ Pro $^{4}$} & & & & & & $0.94(3 \mathrm{H}, \mathrm{m})$ & 21.74 \\
\hline & $a$ & $3.98(1 \mathrm{H}, \mathrm{m})$ & 59.03 & & $\mathrm{NH}$ & 7.65 (1H, br.s) & \\
\hline & $\beta$ & $2.28(1 \mathrm{H}, \mathrm{m})$ & 28.78 & & $C=O$ & & 171.50 \\
\hline & & $2.06(1 \mathrm{H}, \mathrm{m})$ & & & & & \\
\hline & $\gamma$ & $1.94(1 \mathrm{H}, \mathrm{m})$ & 24.68 & & & & \\
\hline & & $1.69(1 \mathrm{H}, \mathrm{m})$ & & $11 e^{9}$ & & & \\
\hline & $\delta$ & $3.94(1 \mathrm{H}, \mathrm{m})$ & 48.06 & & $a$ & $4.34(1 \mathrm{H}, \mathrm{m})$ & 58.71 \\
\hline & & $3.69(1 \mathrm{H}, \mathrm{m})$ & & & $\beta$ & $1.99(1 \mathrm{H}, \mathrm{m})$ & 36.73 \\
\hline & $C=O$ & & 170.69 & & Y & $1.51(2 \mathrm{H}, \mathrm{m})$ & 25.37 \\
\hline \multirow[t]{7}{*}{ Pro $^{5}$} & & & & & $\gamma_{\mathrm{Me}}$ & $0.94(3 \mathrm{H}, \mathrm{m})$ & 16.02 \\
\hline & $a$ & $4.13(1 \mathrm{H}, \mathrm{m})$ & 61.28 & & $\delta_{\mathrm{Me}}$ & $0.88(3 \mathrm{H}, \mathrm{m})$ & 11.78 \\
\hline & $\beta$ & $1.94(2 \mathrm{H}, \mathrm{m})$ & 32.11 & & $\mathrm{NH}$ & $6.74(1 \mathrm{H}, \mathrm{m})$ & \\
\hline & $\gamma$ & $1.51(1 \mathrm{H}, \mathrm{m})$ & 21.99 & & $C=O$ & & 172.42 \\
\hline & & $1.14(1 \mathrm{H}, \mathrm{m})$ & & & & & \\
\hline & $\delta$ & $3.30(2 \mathrm{H}, \mathrm{m})$ & 47.39 & & & & \\
\hline & $C=O$ & & 172.98 & & & & \\
\hline
\end{tabular}

these accessions may contain different sequences and/or may differ in their transcription, translation, and/or post-translational modification of LINUSORB B compared to 'CDC Bethune'.
LINUSORB B encodes a gene that contains one copy of each of the linear precursor orbitides of $\mathbf{1}, \mathbf{3}$ and $\mathbf{8}$. These orbitides are expressed equally in 'CDC Bethune', as in all other accessions within the FCC with the 
exception of 'Hollandia' and 'Z 11637' [23]. We studied the orbitide encoding region of LINUSORB $B$ to determine if an alteration in this gene was responsible for the unusual apparent concentration ratio of orbitides and low total orbitide content observed in 'Hollandia' and ' $\mathrm{Z}$ 11637'. Sequencing of the orbitide encoding region of this gene in 'Hollandia' and ' $\mathrm{Z}$ 11637' revealed a $117 \mathrm{bp}$ deletion (Additional file 10). The transcribed gene encodes an orbitide with amino acid sequence MLIPPFFLI and corresponds to the deduced structure of 18. As the size of the orbitide peptides repeat unit is $117 \mathrm{bp}$, the deletion maintains the reading frame of the gene and results in the synthesis of two orbitides (18 and 7) instead of three (1,2 and 7).

\section{Discussion}

The deletion precludes expression of intact $\mathbf{1}$ and $\mathbf{2}$, but results in the joining of the $5^{\prime}$ fragments of 2 and the 3 ' portion of 1 to form the novel orbitide 18. Orbitides 1 and 2 have fourteen bp in common (TCCСCСССТTCTTT); the beginning and end of the deletion occurs within this shared sequence for 2 and 1, respectively (Fig. 5). It is not possible to determine the exact nucleotide at which the deletion starts and ends. However, the peptide sequences of Orbitides 1, $\mathbf{2}$ and $\mathbf{1 8}$ are conserved at this location for the 'Hollandia, 'Z11637' and other genotypes. This means that the lesion resulting in Orbitide $\mathbf{1 8}$ occurred at the same nucleotide in this region for Orbitides $\mathbf{1}$ and $\mathbf{2}$ (Fig. 5).

Evidence that the 117 bp deletion occurred between the sequences for Orbitides $\mathbf{2}$ and $\mathbf{1}$ is that the sequence of the PCR fragment from 'Hollandia' and 'Z11637' situated $5^{\prime}$ of Orbtide $\mathbf{2}$ and $3^{\prime}$ ' of Orbitide $\mathbf{1}$ are identical to that of the reference gene sequence from CDC Bethune and from PCR fragments amplified from 16 other genotypes (data not shown). Furthermore, sequence differences unique to the deleted fragment ( 7 nucleotide differences and a $3 \mathrm{bp}$ and a $9 \mathrm{bp}$ insertion) were not observed in the sequence of the PCR product from 'Hollandia' and 'Z11637'. Taken together, the simplest explaination for the observed DNA and orbitide sequence in 'Hollandia' and 'Z11637' is a 117 bp deletion starting in the common 14 bp region of Orbitide 2 and ending at the same nucleotide in Orbitide 1. Alternative explanations are possible, but are not as parsimonious as the one suggested here as they need to explain the conserved sequence identity in the rest of the PCR fragment and the absence of the unique sequence differences located between the Orbitide $\mathbf{2}$ and $\mathbf{1}$ coding regions.

At the amino acid level, the putative linear transcript in ' $Z$ 11637' consists of a fusion of the first three amino acid residues of 2 (MLI), the conserved residues PPFF, contributed either entirely from $\mathbf{1}$ or $\mathbf{2}$ or as a portion from both, and the last two residues of 1 (LI) (Fig. 5). The amplified fragment in 'Hollandia' is similar to that from ' $\mathrm{Z} 11637$ ' and, as a result, the alignment of 'CDC Bethune' with 'Hollandia' is identical to that with 'Z11637'. There were no mutations observed in the DNA coding fragment of $\mathbf{8}$ which explains the comparable expression of $\mathbf{8}$ among 'Hollandia,' ' $\mathrm{Z} 11637$ ' and 'CDC Bethune'. The putative precursor of $\mathbf{1}, \mathbf{7}$ and $\mathbf{1 8}$ is flanked by "DG" and "FGK" amino acid residues at the amino and carboxy termini, respectively. New orbitide 18 is the result of the removal of a whole repeat unit suggesting that orbitide expression is conserved and that a mechansim(s) to delete fragments function(s) to maintain the integrity of the orbitide repeat units. A search for similar, whole orbitide unit, insertions/deletions in the other main orbitide gene (LINUSORB A) to determine whether a consistent mechanism for orbitide gene recombination exists is underway.

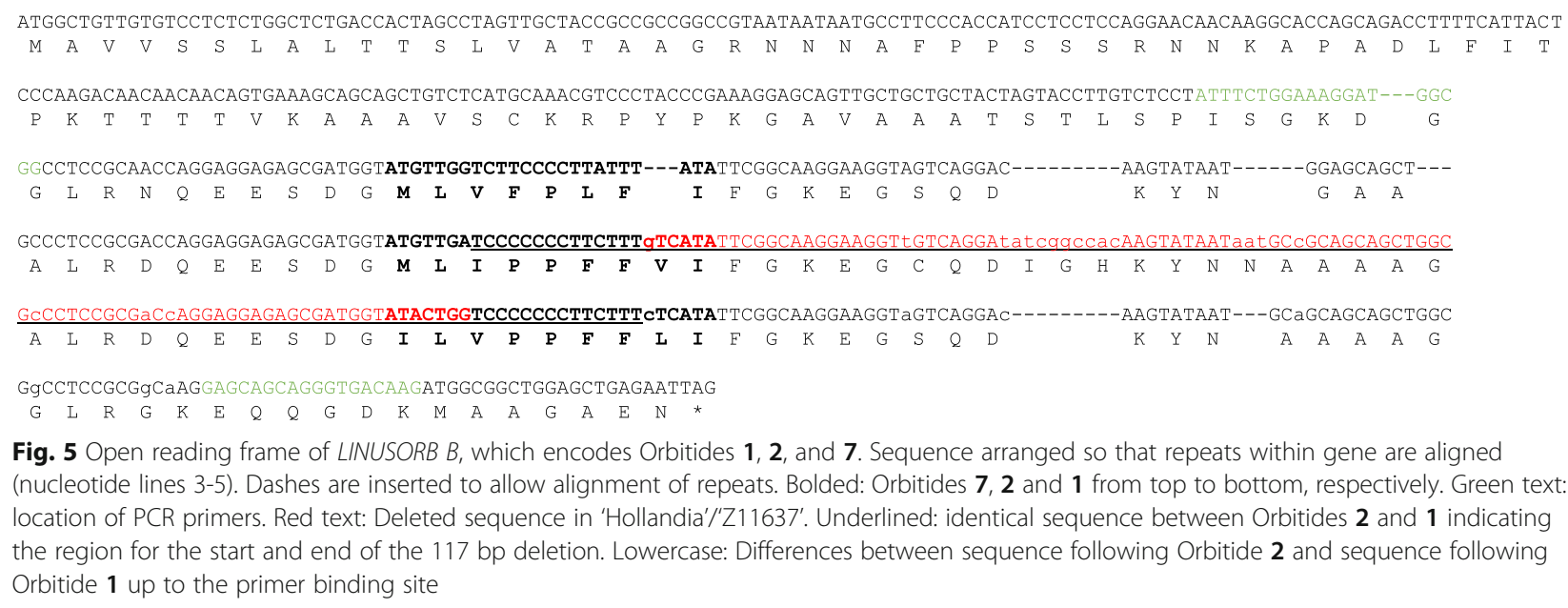

Fig. 5 Open reading frame of $L I N U S O R B$ B, which encodes Orbitides $\mathbf{1}, \mathbf{2}$, and $\mathbf{7}$. Sequence arranged so that repeats within gene are aligned (nucleotide lines 3-5). Dashes are inserted to allow alignment of repeats. Bolded: Orbitides 7, $\mathbf{2}$ and $\mathbf{1}$ from top to bottom, respectively. Green text: location of PCR primers. Red text: Deleted sequence in 'Hollandia'/'Z11637'. Underlined: identical sequence between Orbitides $\mathbf{2}$ and $\mathbf{1}$ indicating the region for the start and end of the 117 bp deletion. Lowercase: Differences between sequence following Orbitide $\mathbf{2}$ and sequence following Orbitide 1 up to the primer binding site 
The mutation event occurring in 'Hollandia' and ' $\mathrm{Z}$ 11637' was determined to be heritable by crossing 'Hollandia' with 'CDC Sorrel' and 'Hollandia' with 'CDC Sanctuary'. The sequence of LINUSORB B in 'CDC Sorrel' and 'CDC Sanctuary' is identical to that of 'CDC Bethune', and, as such, these cultivars expressed 1, 2, 5, 7, 10 and 14 at similar concentrations to the check ' $C D C$ Bethune'. Inheritance of the altered LINUSORB B gene was observed both phenotypically (via HPLC-DAD and mass spectral analyses) and genotypically (PCR and qPCR) in $\mathrm{F}_{3}$ seed. The expected Mendelian ratios for monogenetic inheritance were observed in this population. No distortion of the expected phenotypic ratios was observed in reciprocal crosses in these populations, indicating that maternal factors do not affect orbitide expression.

Although it is difficult to determine the timeline of the DNA variation, we infer that the deletion event probably occurred in a common ancestor of 'Hollandia' and ' $\mathrm{Z}$ 11637 ' as both orignated from the Netherlands. Rapid changes in the flax genome as a response to growth environment has been reported in which DNA variants can be stable or unstably inherited [29]. 'Hollandia' is a flax cultivar in which stable genomic variations have been observed, others including 'Stormont Cirrus,' 'Rembrandt', and 'Liral Monarch' [30]. CA Cullis [30] has suggested that organization of the flax genome contributes to widespread genomic variations that may be observed in flax within a generation. We speculate that the deletion event described here could be an example of this type of genomic reorganization induced by environmental stress. It is also intriguing to speculate on the role of orbitides in flax physiology and agronomic selection. All flax cultivars and accessions examined in the FCC expressed orbitides in their seed [23], however, as demonstrated in this paper, significant alterations in their composition and total concentration are possible.

\section{Conclusions}

The unidentified peak observed in HPLC-DAD chromatograms of extracts from 'Hollandia' and ' $\mathrm{Z}$ 11637' flax cultivars is attributed to novel orbitide 18. Mass spectrometry (high resolution HPLC-ESI-MS and HPLC-ESI-MS/MS) and NMR spectroscopy revealed the structure of 18 as [1-9-N $\alpha \mathrm{C}$ ]-OLIPPFFLI with $m / z$ 1072.6. The analysis of the gene sequence of LINUSORB B in 'Hollandia' and ' $\mathrm{Z}$ 11637' explains the apparently reduced total orbitide concentration by the lack of $\mathbf{1}$ and $\mathbf{2}$, and the expression of 18, as compared with 'CDC Bethune'. Sequencing results also corroborate the amino acid sequence of $\mathbf{1 8}$ deduced from spectroscopy. Future work will include recovery of sequences with similarity to LINUSORB B and LINUSORB A from the entire FCC [24] which covers approximately $95 \%$ of the genetic variation in flax. Correlations between gene structure and orbitide expression will be made once this data is obtained.

\section{Methods \\ Flaxseed}

Seed from the cultivars 'Hollandia' (CN 98056), 'Z 11637' ( $\mathrm{CN}$ 98150), and 'CDC Bethune' were regenerated at Kernen Crop Research Farm, Saskatoon, SK and Morden Research Station, Morden, MB in 2009, 2010, and 2011. Flaxseed was kindly donated by Dr. Scott Duguid (Morden Research Station, MB) and Drs. Helen Booker and Gordon Rowland (Crop Development Centre, Saskatoon SK).

\section{Sample preparation for orbitide composition analysis}

Approximately $120 \mathrm{mg}$ of flaxseed from each accession for each growing season was weighed and placed directly into wells $(\sim 1.8 \mathrm{~mL}$ volume $)$ of 96-well plates. Each sample was prepared according to Burnett et al. [23] in quadruplicate to enable replicate composition analyses for oxidized and unoxidized (native) extracts. Specifically, pre-heated $\mathrm{H}_{2} \mathrm{O}\left(60{ }^{\circ} \mathrm{C}\right)$ was added to each well at a seed water ratio of 1:10 $(w / v)$ and wells were covered with a 96-well plate sealing mat (square cap). Covered plates were incubated at $60{ }^{\circ} \mathrm{C}$ for $2 \mathrm{~h}$ and then gum extracts were removed via pipette. The degummed seeds were ground at 1400 strokes per min for 10 min using a 2010 Geno/grinder (SPEX CertiPrep, Inc., Methucen, $\mathrm{NJ}$ ) and spherical 5-mm zirconia grinding media (1 per well). A $100 \mu \mathrm{L}$ aliquot of internal standard [1-9$\mathrm{N} \alpha \mathrm{C}],[1-\mathrm{Abu}]$-linusorb B2 $(0.1 \mathrm{mg} / \mathrm{mL}$ in $\mathrm{MeOH})$, prepared as previously reported, [31] was added to each well. Subsequently, $860 \mu \mathrm{L}$ of methanol:water $(78: 22, \mathrm{v} /$ v) was added to each well to make a final dilution of 1:8 $(\mathrm{w} / \mathrm{v})$. Samples were mixed for $2 \mathrm{~min}$ at 1400 strokes per min and were subsequently incubated at $60{ }^{\circ} \mathrm{C}$ for $2 \mathrm{~h}$. Samples were centrifuged at $1760 \times \mathrm{g}$ for $20 \mathrm{~min}$ and a $400 \mu \mathrm{L}$ aliquote of the resulting supernatant was transferred to a 96-well filter plate.

Filter plates were covered and placed on top of receiving 96-well plates and assembled plates were placed in a centrifuge for filtration at $1760 \times \mathrm{g}$ for $10 \mathrm{~min}$. Filtered extracts (100 $\mu \mathrm{L}$ aliquots) were transferred to 96-well HPLC trays and were subsequently oxidized with $\mathrm{H}_{2} \mathrm{O}_{2}\left(50 \mu \mathrm{L}, 4.5 \%\right.$ in $\mathrm{H}_{2} \mathrm{O}$, v/v) or diluted with $\mathrm{H}_{2} \mathrm{O}(50 \mu \mathrm{L})$ such that each cultivar per harvest year had replicates for each treatment. After $1 \mathrm{~h}$ at room temperature, the oxidized extracts were quenched with $\mathrm{Na}_{2} \mathrm{~S}_{2} \mathrm{O}_{3}(150 \mu \mathrm{L}, 0.2 \mathrm{M})$ in $70 \%$ aq. $\mathrm{MeOH}$, whereas $70 \%$ aq. $\mathrm{MeOH}(150 \mu \mathrm{L})$ was added to the diluted extracts. The 96-well trays were placed in an HPLC-DAD, as described below, with an autoinjector for sample analyses. Extracts were also analyzed via high resolution HPLC Electrospray Ionization mass 
spectrometry (HR-HPLC-ESI-MS and HPLC-ESI-MS/ MS).

\section{Extraction and isolation}

Orbitides were extracted from 'Hollandia' (CN 98056) and ' $\mathrm{Z}$ 11637' (CN 98150) seed regenerated in 2009. Seed samples from Saskatoon, SK and Morden, MB, were combined based on flax accession (total mass of extracted flaxseed was $80 \mathrm{~g}$ ) and were ground prior to extraction with $70 \% \mathrm{MeOH}(1: 20 \mathrm{v} / \mathrm{v}, \times 2)$. Each sample was incubated at $60{ }^{\circ} \mathrm{C}$ for $2 \mathrm{~h}$. Aliquots of each aqueous methanolic extract were filtered through $0.45 \mu \mathrm{m}$ PTFE membranes for HPLC-DAD and HPLC-ESI-MS analyses. Then, extracts were freed of solvent using a rotary evaporator to yield crude orbitide extracts (total mass $4.95 \mathrm{~g}$ ). Mass spectra of all 'Hollandia' and 'Z 11637' extracts indicated the presence of $\mathbf{1 8}$ possessing quasimolecular ion peak at $m / z 1072.6$, in addition to other known orbitides.

Conversion of methionine-containing orbitides to their methionine $S$-oxide-containing form is necessary to simplify orbitide peak chromatographic separation, and increase the concentration of novel orbitides in a single oxidation state. Consequently, crude orbitide extracts were oxidized with $\mathrm{H}_{2} \mathrm{O}_{2}$ prior to flash column chromatography as follows. Extracts were suspended in $\mathrm{MeOH}$ $(5 \mathrm{~mL}, \times 2)$, filtered through $0.45 \mu \mathrm{m}$ PTFE membranes, and subsequently combined with $\mathrm{H}_{2} \mathrm{O}_{2}(1 \mathrm{~mL}, 30 \%$ in $\left.\mathrm{H}_{2} \mathrm{O}, \mathrm{v} / \mathrm{v}\right)$. Oxidation was monitored by HPLC-DAD and upon conversion of $\mathbf{1 8}$ to $\mathbf{1 9}$, the reaction mixture was quenched with saturated $\mathrm{Na}_{2} \mathrm{~S}_{2} \mathrm{O}_{3}$ in $70 \%$ aq. $\mathrm{MeOH}$ $(10 \mathrm{~mL})$, then filtered. The sample was freed of solvent using a rotary evaporator (dry mass of sample $4.56 \mathrm{~g}$ ). The oxidized extract was subjected to flash column chromatography on silica gel 60 (40-63 $\mu$ m particle size, EMD Chemicals). Sequential elution with the following solvent systems was conducted (each $200 \mathrm{~mL}$, with each eluent being divided into two fractions): (a) $n$-hexane; (b) $20 \%$ EtOAc in $n$-hexane; (c) $50 \%$ EtOAc in $n$-hexane; (d) $80 \%$ EtOAc in $n$-hexane; (e) $100 \%$ EtOAc; (f-j) $2 \%$ $\mathrm{MeOH}$ in $\mathrm{CH}_{2} \mathrm{Cl}_{2}$ to $10 \% \mathrm{MeOH}$ in $\mathrm{CH}_{2} \mathrm{Cl}_{2}$ using $2 \%$ $\mathrm{MeOH}$ increments. Each fraction collected was analyzed via HPLC-DAD and HPLC-ESI-MS. Fractions determined to contain substantial amounts of $\mathbf{1 9}(\mathrm{m} / \mathrm{z} 1088$. 6) were purified using preparative reversed-phase chromatography.

\section{HPLC-DAD analyses \\ Analytical}

Analyses of FCC orbitide composition were performed on a 1200 series HPLC system (Agilent Technologies Canada, Mississauga, ON) equipped with a quaternary pump, autosampler, photodiode-array detector (wavelength range 190-300 $\mathrm{nm}$ ), and a degasser.
Chromatographic separations were carried out on $50 \mathrm{~mm} \times 4.6 \mathrm{~mm}$ i.d., reversed phase Chromolith SpeedRod RP-18e columns (Merck KGaA, Darmstadt, Germany) equipped with in-line filters. The mobile phase consisted of a linear gradient of $\mathrm{H}_{2} \mathrm{O}$ and acetonitrile $\left(\mathrm{CH}_{3} \mathrm{CN}\right)$ (70:30 to 30:70 in $4 \mathrm{~min}$, to 10:90 in 0 . $5 \mathrm{~min}$, to $70: 30$ in $0.5 \mathrm{~min}$, to equilibration for $1 \mathrm{~min}$ ) at a flow rate of $2 \mathrm{~mL} / \mathrm{min}$ [31]. All analyses were conducted at $23{ }^{\circ} \mathrm{C}$ using $10 \mu \mathrm{L}$ injection volumes and recording absorbance over the entire UV spectrum. Peak area integration was conducted at a wavelength of $214 \mathrm{~nm}$ with a $10 \mathrm{~nm}$ bandwidth. All samples analyzed via HPLC-DAD and HPLC-MS were previously filtered through $0.45 \mu \mathrm{m}$ PTFE membranes. The molar extinction coefficients at $214 \mathrm{~nm}$ of all orbitides discussed in this manuscript are similar and, therefore, $\mathrm{A}_{214}$ is proportional to orbitide concentration. Pure orbitide standards were not used to determine either matrix effects or concentration. All concentrations are compared based on their $\mathrm{A}_{214}$ during elution from an HPLC column.

\section{Preparative}

Preparative reversed phase chromatography was performed on an Agilent 1200 series HPLC system (Agilent Technologies Canada, Mississauga, ON) equipped with a Chromolith $^{\circ}$ SemiPrep RP-18e column $(100 \times 10 \mathrm{~mm}$ i. d.), and a UV/VIS detector operating at a wavelength of $214 \mathrm{~nm}$. The mobile phase consisted of $\mathrm{H}_{2} \mathrm{O}-\mathrm{CH}_{3} \mathrm{CN}$ (55:45 for $12 \mathrm{~min}$, to $5: 95$ in $1.0 \mathrm{~min}$, to $55: 45$ in 1 . $0 \mathrm{~min}$, to equilibration for $6 \mathrm{~min}$ ) at a flow rate of $3 \mathrm{~mL} /$ min. All preparative separations were performed at ambient temperature.

\section{Mass spectral analyses}

High resolution HPLC-ESI-MS and HPLC-ESI-MS/MS analyses were performed on an Agilent 1200 series HPLC system connected directly to a micrOTOF-Q II hybrid quadrupole time of flight MS/MS (Bruker Daltonik GmbH, Bremen, Germany) with Apollo II electrospray ionization (ESI) ion source at a capillary voltage of $-4500 \mathrm{~V}$, nebulizer gas at 4.0 bar, and drying gas temperature held at $200{ }^{\circ} \mathrm{C}$. Chromatographic separation for MS analyses was achieved at ambient temperature using a Chromolith ${ }^{\circ}$ FastGradient RP-18e column $(50 \mathrm{~mm} \times 2.0 \mathrm{~mm}$ i.d., Merck KGaA, Darmstadt, Germany). The mobile phase consisted of a linear gradient of $0.1 \%$ formic acid in $\mathrm{H}_{2} \mathrm{O}$ and $0.1 \%$ formic acid in $\mathrm{CH}_{3} \mathrm{CN}$ (60:40 for $2 \mathrm{~min}$, to 10:90 in $8 \mathrm{~min}$, to 60:40 in $0.5 \mathrm{~min}$, to equilibration for $5.5 \mathrm{~min}$ ) at a flow rate of $0.4 \mathrm{~mL} / \mathrm{min}$ [16]. HPLC-ESI-MS/MS analyses were conducted on a Bruker micrOTOF-Q II Mass Spectrometer using identical parameters to those described for HRHPLC-ESI-MS. 
Structural analysis via nuclear magnetic resonance (NMR) Proton NMR spectra were recorded on a $600 \mathrm{MHz}$ Bruker Avance spectrometer (5 mm PABBO BB-probe head; TopSpin 3.2 software). The ${ }^{1} \mathrm{H}$ NMR spectra $(600 \mathrm{MHz})$ chemical shifts $(\delta)$ values are reported in parts per million (ppm) relative to the internal standard TMS. The $\delta$ values are referenced to $\mathrm{CDCl}_{3}$ at $7.26 \mathrm{ppm}$, and multiplicities are indicated by the following symbols: $\mathrm{s}=$ singlet, $\mathrm{d}=$ doublet, $\mathrm{dd}=$ doublet of doublets, $\mathrm{m}=$ multiplet, and br = broad. For ${ }^{13} \mathrm{C}$ NMR $(125.8 \mathrm{MHz})$, the chemical shift $(\delta)$ values were referenced to $\mathrm{CDCl}_{3}$ (77.23 ppm).

\section{Orbitide gene sequence analyses}

Primers were designed to amplify the portions of LINU$S O R B B$ which encoded for Orbitides 1, 3, and 8. The sequence of this gene has been confirmed in previous work [1-3], as well as other sources, and the identifier, LINUSORB B, is used throughout this paper to maintain consistency with our proposed systematic nomenclature [22]. Flax accessions and cultivars examined for sequence analysis were 'Hollandia,' 'Z 11637', and 'CDC Bethune'. A quick alkaline lysis method was used to extract crude total DNA from leaves of 14 day old seedlings [32]. Crude extracts $(1 \mu \mathrm{L})$ were used as templates for PCR amplification of a 369 bp fragment using forward (5'ATTTCTGGAAAGGATGGCGG3') and reverse (5'CT TGTCACCCTGCTGCTC3') primers with annealing temperatures of 58.2 and $58.0{ }^{\circ} \mathrm{C}$, respectively. The sizes of the fragments from different accessions were compared using agarose gel electrophoresis. The fragments from two PCRs (each $25 \mu \mathrm{L}$ ) were purified using a Qiagen DNAesy PCR purification kit and were then sequenced using the amplification primers or one of two internal primers (5'CGGCATTATTATACTTGTGGCC G3' or 5'CGGCCACAAGTATAATAATGCCG3'). PCR fragment sequencing was performed by the National Research Council (NRC) Canada, Saskatoon, DNA Sequencing Facility. PCR product sequences were aligned against the LINUSORB B sequence from 'CDC Bethune' using Geneious 6.0 (Biomatters Inc., Auckland, New Zealand).

\section{Additional files}

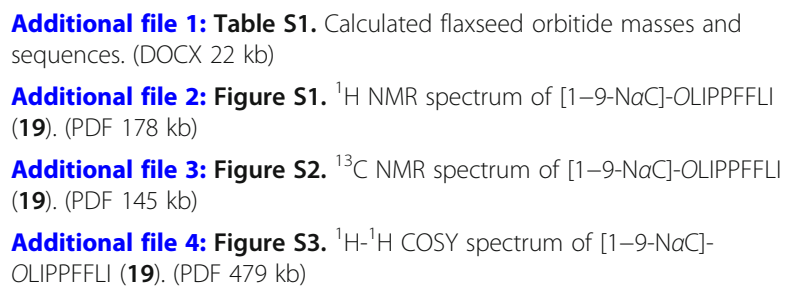

Additional file 5: Figure S4. DEPT spectrum of [1-9-NaC]-OLIPPFFLI (19). (PDF $145 \mathrm{~kb}$ )

Additional file 6: Figure S5. ${ }^{1} \mathrm{H}^{13} \mathrm{C}$ HMBC spectrum of [1-9-NaC]OLIPPFFLI (19). (PDF $189 \mathrm{~kb}$ )

Additional file 7: Figure $56 .{ }^{1} \mathrm{H}-{ }^{13} \mathrm{C} \mathrm{HSQC}$ spectrum of [1-9-NaC]OLIPPFFLI (19). (PDF $229 \mathrm{~kb}$ )

Additional file 8: Figure S7. ${ }^{1} \mathrm{H}-{ }^{1} \mathrm{H}$ NOESY spectrum of [1-9-NaC]OLIPPFFLI (19). (PDF $476 \mathrm{~kb}$ )

Additional file 9: Figure S8. ${ }^{1} \mathrm{H}-{ }^{1} \mathrm{H}$ TOCSY spectrum of [1-9-NaC]OLIPPFFLI (19). (PDF $763 \mathrm{~kb}$ )

Additional file 10: Hollandia,Bethune_Orbitide_seq.fa sequence obtained from Sanger sequencing of the Hollandia/Z11637 orbitide [18, 8] PCR fragment and the CDC Bethune orbitide $[\mathbf{1}, \mathbf{3}, \mathbf{8}] \mathrm{PCR}$ fragment. (FA 717 bytes)

\section{Abbreviations}

CDC: Crop Development Centre; CN: Canadian National; COSY: Correlation spectroscopy; FCC: Flax core collection; HMBC: Heteronuclear multiple-bond correlation; HMQC: Heteronuclear multiple quantum correlation; HPLCDAD: High performance liquid chromatography with diode array detector; HPLC-ESI-MS/MS: High resolution high performance liquid chromatography with electrospray ionization tandem mass spectrometry; HR-HPLC-ESIMS: High resolution high performance liquid chromatography with electrospray ionization mass spectrometry; NCBI: National Center for Biotechnology Information; NMR: Nuclear Magnetic Resonance; NOESY: Nuclear Overhauser effect spectroscopy; PGRC: Plant Gene Resources of Canada; TOCSY: Total correlation spectroscopy

\section{Funding}

The work was part of the Total Utilization Flax GENomics (TUFGEN) project \#1309 funded by Genome Canada and the Saskatchewan Flax Development Commission (SFDC). Financial support for the author's work was also provided by the Saskatchewan Ministry of Agriculture - Agricultural Development Fund (Grants 20080205, 20120099, and 20120146).

\section{Availability of data and materials}

The majority of the data generated or analyzed during this study are included in this published article and its supplementary information files. Excluded datasets are available from the corresponding author on a reasonable request.

\section{Authors' contributions}

PB acquired and interpreted mass spectral data, isolated orbitide for subsequent analyses, conducted analyses on $\mathrm{F}_{3}$ seed, and was a major contributor in writing the manuscript. LY performed all gene sequence analyses of the orbitides, interpreted the corresponding data generated and co-wrote the manuscript. CO conducted orbitide profiling of the cultivars as part of her M.Sc. thesis. PJ performed NMR characterization and DO was involved in acquisition and interpretation of mass spectral data. MR supervised the work performed and contributed intellectually to the manuscript. All authors read and approved the final manuscript.

Ethics approval and consent to participate Not applicable.

Competing interests

The authors declare that they have no competing interests.

\section{Publisher's Note}

Springer Nature remains neutral with regard to jurisdictional claims in published maps and institutional affiliations.

\section{Author details}

${ }^{1}$ Department of Plant Sciences, College of Agriculture and Bioresources, University of Saskatchewan, Saskatoon, SK S7N 5A8, Canada. ${ }^{2}$ Department of Food and Bioproduct Sciences, College of Agriculture and Bioresources, University of Saskatchewan, Saskatoon, SK S7N 5A8, Canada. ${ }^{3}$ Guangdong Saskatchewan Oilseed Joint Laboratory, Department of Food Science and Engineering, Jinan University, Guangzhou 510632, Guangdong, China. 
Received: 3 January 2018 Accepted: 30 April 2018

Published online: 21 May 2018

\section{References}

1. Arnison PG, Bibb MJ, Bierbaum G, Bowers AA, Bugni TS, Bulaj G, Camarero $J A$, Campopiano DJ, Challis GL, Clardy J, et al. Ribosomally synthesized and post-translationally modified peptide natural products: overview and recommendations for a universal nomenclature. Nat Prod Rep. 2013;30(1): 108-60.

2. Condie JA, Nowak G, Reed DW, Balsevich JJ, Reaney MJT, Arnison PG, Covello PS. The biosynthesis of Caryophyllaceae-like cyclic peptides in Saponaria vaccaria L. from DNA-encoded precursors. Plant J. 2011;67(4):682-90.

3. Covello PS, Datla RSS, Stone SL, Balsevich JJ, Reaney MJ, Arnison PG, Condie JA. DNA sequences encoding caryophyllaceae and caryophyllaceae-like cyclopeptide precursors and methods of use. 2010; US Patent Application 2012/0058905A1.

4. Driggers EM, Hale SP, Lee J, Terrett NK. The exploration of macrocycles for drug discovery-an underexploited structural class. Nat Rev Drug Discov. 2008; $7(7): 608-24$.

5. Wieczorek Z, Bengtsson B, Trojnar J, Siemion IZ. Immunosuppressive activity of cyclolinopeptide A. Peptide Res. 1991;4(5):275-83.

6. Kessler H, Klein M, Müller A, Wagner K, Bats JW, Ziegler K, Frimmer M. Conformational prerequisites for the in vitro inhibition of cholate uptake in hepatocytes by cyclic analogues of antamanide and somatostatin. Angew Chem Int Ed Engl. 1986;25(11):997-9.

7. Gaymes TJ, Cebrat M, Siemion IZ, Kay JE. Cyclolinopeptide A (CLA) mediates its immunosuppressive activity through cyclophilin-dependent calcineurin inactivation. FEBS Lett. 1997:418(1-2):224-7.

8. Drygała P, Olejnik J, Mazur A, Kierus K, Jankowski S, Zimecki M, Zabrocki J. Synthesis and immunosuppressive activity of cyclolinopeptide $\mathrm{A}$ analogues containing homophenylalanine. Eur J Med Chem. 2009;44(9):3731-8.

9. Morita H, Shishido A, Matsumoto T, Itokawa H, Takeya K. Cyclolinopeptides B-E, new cyclic peptides from Linum usitatissimum. Tetrahedron. 1999;55(4): $967-76$.

10. Siemion IZ, Cebrat M, Wieczorek Z. Cyclolinopeptides and their analogs-a new family of peptide immunosuppressants affecting the calcineurin system. Arch Immunol Ther Exp. 1999;47(3):143-53.

11. Górski A, Kasprzycka M, Nowaczyk M, Wieczoreck Z, Siemion IZ, Szelejewski W, Kutner A. Cyclolinopeptide: a novel immunosuppressive agent with potential anti-lipemic activity. Transplant Proc. 2001;33(1):553.

12. Benedetti E, Pedone C. Cyclolinopeptide A: inhibitor, immunosuppressor or other? J Pept Sci. 2005;11(5):268-72.

13. Picur B, Cebrat M, Zabrocki J, Siemion IZ. Cyclopeptides of Linum usitatissimum. J Pept Sci. 2006;12:569-74.

14. Morita H, Takeya K. Bioactive cyclic peptides from higher plants. Heterocycles. 2010;80:739-64.

15. Goyal A, Sharma V, Upadhyay N, Gill S, Sihag M. Flax and flaxseed oil: an ancient medicine \& modern functional food. J Food Sci Technol. 2014;51(9): 1633-53.

16. Okinyo-Owiti DP, Jadhav PD, Bauer R, Reaney MJT, Dong Q, Ling B, Yang J, Maley JM, Sammynaiken R. Evaluating the cytotoxicity of flaxseed orbitides for potential cancer treatment. Toxicol Rep. 2015;2:1014-8.

17. Shim YY, Gui B, Arnison PG, Wang Y, Reaney MJT. Flaxseed (Linum usitatissimum L.) bioactive compounds and peptide nomenclature: a review. Trends Food Sci Technol. 2014;38(1):5-20.

18. Burnett P-GG, Jadhav PD, Okinyo-Owiti DP, Poth AG, Reaney MJT. Glycinecontaining flaxseed orbitides. J Nat Prod. 2015;78(4):681-8.

19. Gui B, Shim YY, Datla RSS, Covello PS, Stone SL, Reaney MJT. Identification and quantification of cyclolinopeptides in five flaxseed cultivars. J Agric Food Chem. 2012;60(35):8571-9.

20. Okinyo-Owiti DP, Young L, Burnett PGG, Reaney MJT. New flaxseed orbitides: detection, sequencing, and $15 \mathrm{~N}$ incorporation. Pept Sci. 2014;102(2):168-75.

21. You FM, Xiao J, Li P, Yao Z, Jia G, He L, Zhu T, Luo MC, Wang X, Deyholos MK, Cloutier S. Chromosome-scale pseudomolecules refined by optical, physical, and genetic maps in flax. Plant J. 2018.

22. Shim YY, Young LW, Arnison PG, Gilding E, Reaney MJT. Proposed Systematic Nomenclature for Orbitides. J Natural Products. 2015;78 (4):645-52.

23. Burnett P-GG, Olivia CM, Okinyo-Owiti DP, Reaney MJT. Orbitide composition of the flax Core collection (FCC). J Agric Food Chem. 2016;64 5197-206.
24. Diederichsen A, Kusters P, Kessler D, Bainas Z, Gugel R. Assembling a core collection from the flax world collection maintained by plant gene resources of Canada. Genet Resour Crop Ev. 2013;60(4):1479-85.

25. Soto-Cerda BJ, Diederichsen A, Ragupathy R, Cloutier S. Genetic characterization of a core collection of flax (Linum usitatissimum L.) suitable for association mapping studies and evidence of divergent selection between fiber and linseed types. BMC Plant Biol. 2013;13(78):1-15.

26. Stefanowicz P. Detection and sequencing of new cyclic peptides from linseed by electrospray ionization mass spectrometry. Acta Biochim Pol. 2001;48(4):1125-9.

27. Altschul SF, Madden TL, Schäffer AA, Zhang J, Zhang Z, Miller W, Lipman DJ Gapped BLAST and PSI-BLAST: a new generation of protein database search programs. Nucleic Acids Res. 1997;25(17):3389-402.

28. Gertz EM, Yu Y-K, Agarwala R, Schäffer AA, Altschul SF. Composition-based statistics and translated nucleotide searches: improving the TBLASTN module of BLAST. BMC Biol. 2006;4:41.

29. Cullis CA. DNA differences between flax genotrophs. Nature. 1973;243:515-6.

30. Cullis CA. Mechanisms and control of rapid genomic changes in flax. Ann Bot. 2005;95(1):201-6.

31. Olivia CM, Burnett P-GG, Okinyo-Owiti DP, Shen J, Reaney MJT. Rapid reversed-phase liquid chromatography separation of cyclolinopeptides with monolithic and microparticulate columns. J Chromatogr B. 2012;904:128-34.

32. Young L, Hammerlindl J, Babic V, McLeod J, Sharpe A, Matsalla C, Bekkaoui F, Marquess L, Booker H. Genetics, structure, and prevalence of FP967 (CDC Triffid) T- DNA in flax. SpringerPlus. 2015;4(1):1-9.

\section{Ready to submit your research? Choose BMC and benefit from:}

- fast, convenient online submission

- thorough peer review by experienced researchers in your field

- rapid publication on acceptance

- support for research data, including large and complex data types

- gold Open Access which fosters wider collaboration and increased citations

- maximum visibility for your research: over $100 \mathrm{M}$ website views per year

At BMC, research is always in progress.

Learn more biomedcentral.com/submissions 